\author{
Ewelina Adamik \\ Instytut Filologii Polskiej \\ Uniwersytet Wrocławski \\ e-mail: ewelina.adamik@uwr.edu.pl \\ ORCID: 0000-0001-5104-2487
}

\title{
Paryż Kossaków. Śladami wspomnień rodzinnych
}

W XIX wieku stolica Francji stała się miejscem twórczej działalności wielu słynnych artystów, co znacząco wpłynęło na renomę miasta, zwanego już wówczas centrum światowej kultury. Od połowy XIX stulecia Paryż zaczął odgrywać dużą rolę także w życiorysach najznamienitszych osobistości z familii Kossaków. Bywał w nim m.in.: ceniony batalista Juliusz Kossak (1824-1899), jego syn - Wojciech Kossak (1856-1942), poetka Maria Pawlikowska-Jasnorzewska (1891-1945) oraz satyryczka Magdalena Samozwaniec (1894-1972). Kontakty zarówno z paryską kulturą, jak też jej twórcami, $\mathrm{w}$ tym $\mathrm{z}$ niezwykle barwną i liczną bohemą, wywarły wpływ na sztukę Kossaków, w której intensywniej zaczęły wybrzmiewać najmodniejsze wówczas w Europie trendy estetyczne. W artykule naszkicowane zostaną relacje Kossaków z Paryżem poprzez przywołanie najważniejszych faktów biograficznych łączących ich z tym miastem. Odtwarzając je można sformułować tezę, że frankofilia była przez nich niejako dziedziczona.

Juliusz Kossak związał swój ród z co najmniej dwoma europejskimi miastami. Jednym z nich był Kraków, od $1869^{1}$ roku siedziba rodziny ${ }^{2}$, drugim -

\footnotetext{
1 Rok ten został podany we wspomnieniach Wojciecha Kossaka [zob. W. Kossak, Wspomnienia, oprac. K. Olszański, Warszawa 2016, s. 73].

2 Magdalena Samozwaniec wspomina, że parcela, którą Juliusz Kossak zakupił od pani Zaleskiej, mieściła się wówczas poza granicami miasta - Kossakówka zlokalizowana przy placu Latarnia (następnie przy placu Juliusza Kossaka 4) należała do wsi Zwierzyniec [zob. M. Samozwaniec, Z pamiętnika niemłodej już mężatki, oprac. R. Podraza, Warszawa 2010; M. Samozwaniec, Moich listów nie pal, oprac. R. Podraza, Warszawa 2014, s. 217-219].
} 
Paryż. W 1855 roku wraz z małżonką, Zofią z Gałczeńskich, Kossak wyemigrował do Francji ${ }^{3}$. Kossakowie pozostali w Paryżu przez pięć lat. Batalista pobierał $\mathrm{w}$ tym czasie nauki malarskie oraz odwiedzał salony sztuk pięknych, w których wystawiano dzieła polskich artystów ${ }^{4}$. Młode małżeństwo podczas pobytu we Francji doczekało się trojga dzieci ${ }^{5}$. Osobliwym przypadkiem okazał się akt narodzin bliźniaków - Wojciecha i Tadeusza. Wojciech Kossak urodził się w noc sylwestrową z roku 1856 na 1857 jeszcze przed północą, zaś jego brat Tadeusz pojawił się na świecie po godzinie dwudziestej czwartej. Według kodeksu napoleońskiego starszym z bliźniaków był ten, który został powity jako wtóry ${ }^{6}$.

Wojciech Horacy Kossak drugie imię otrzymał na cześć swojego ojca chrzestnego - Horacego Verneta, słynnego malarza, który udzielał lekcji rysunku Juliuszowi ${ }^{7}$. Fakt ten świadczył o bliskiej zażyłości rodziny z francuską bohemą. Kossakowie nie tylko spotykali w Paryżu najwybitniejszych przedstawicieli ówczesnego świata artystycznego, ale także elitę Wielkiej Emigracji, tj. księcia Adama Czartoryskiego, generała Henryka Dembińskiego, generała Władysława Zamoyskiego czy generała Józefa Wysockiego. Juliusz widywał również rodzinę Eustachego Januszkiewicza ${ }^{8}$.

Mieszkanie, w którym zatrzymali się Kossakowie, znajdowało się w centrum Paryża, w dzielnicy pełnej monumentalnych budowli, pamiętających dawne dzieje francuskiej stolicy. Wojciech Kossak, liczący sobie wówczas najwyżej cztery lata, zapamiętał tę okolicę z wieloma detalami. W swoich wspomnieniach, spisanych $\mathrm{w}$ dojrzałym wieku, prezentuje obraz tego miejsca, nie szczędząc pochwalnych słów:

Rodzice moi mieszkali na rue des Vanneaux, w tej dzielnicy tego cudownego miasta, gdzie z jednej strony panuje w rezydencjach takich, jak Palais Mazarin, jak Sorbonne, École des Beaux Arts, le Luxembourg duch kultury francuskiej, z drugiej zaś, u stóp górującej nad Paryżem kopuły złocistej Inwalidów, żyła przyszłością i teraźniejszością wojenna gloria Francji. Sylweta tego arcydzieła architektury, jakim jest Hôtel des Invalides, to jedno z najpierwszych mglistych wspomnień mojego dzieciństwa9.

\footnotetext{
3 K. Olszański, Wstęp, w: W. Kossak, Wspomnienia, s. 6.

4 F. Ziejka, Mój Paryż, Kraków 2008, s. 125.

5 W Paryżu Zofia Kossak powiła bliźniaków - Wojciecha i Tadeusza, następnie w 1858 roku Stefana. Po powrocie do Warszawy rodzina powiększyła się jeszcze o dwie córki - Zofię i Jadwigę.

6 W. Kossak, Wspomnienia, s. 51.

7 Tamże, s. 52.

8 Tamże, s. 55-56.

9 Tamże, s. 53.
} 
Wojciech Kossak powrócił do Paryża w 1877 roku - dwudziestojednoletni malarz ukończył wtedy służbę wojskową i zdał egzamin oficerski ${ }^{10}$. Stolica Francji była właściwym miejscem dla młodego batalisty, który chciał pobierać nauki u największych mistrzów. Juliusz Kossak wskazał synowi szkołę Léonna Bonnata oraz nauczyciela akademizmu - Alexandre'a Cabanela ${ }^{11}$. Artysta zatrzymał się u hrabiego Konstantego Branickiego oraz hrabiny Jadwigi z Potockich przy rue de Penthiévre. Wojciech zapamiętał to miejsce jako ognisko polskości, które zastąpiło gasnący w tamtym czasie Hotel Lambert ${ }^{12}$.

Polski malarz - Henryk Rodakowski, będący w przyjaznych stosunkach z Leonem Bonnatem, napisał do artysty list polecający Kossaka juniora ${ }^{13}$. Wojciech zdał egzamin pozytywnie i został studentem szkoły francuskiego naturalisty ${ }^{14}$. Nauki pobierał przez pięć lat. $W$ tym czasie u szczytu sławy stał inny polski malarz - Józef Chełmoński, a pierwsze kroki stawiał Teodor Axentowicz, który spędził w Paryżu 13 lat, oraz Jacek Malczewski ${ }^{15}$.

Twórczość Kossaka bardzo szybko zaczęła być przedstawiana artystycznemu monde'u. Jak zauważa Kazimierz Olszański, już w 1878 roku Salon Paryski wystawił Autoportret w mundurze ułańskim, rok później prezentowano Manewry $w$ Galicji, następnie, w 1882 roku, Portret panny Celiny D. W 1890 roku Kossak otrzymał w Paryżu dyplom honorowy za dzieło Wzięcie do niewoli Tyszkiewicza w czasie odwrotu spod Moskwy ${ }^{16}$. Kossak junior zyskał rozpoznawalność nie tylko ze względu na zdolności malarskie, ale także z powodu wyjątkowej aparycji, o czym wspomina w swoich emigracyjnych zapiskach Maria Pawlikowska-Jasnorzewska:

Tatko miał tak piękną rękę, że w Paryżu, gdy był młody, robiono mu z niej odlew dla rzeźbiarzy. Oczy miał z tęczą, czarne, miodowo słodkie. Wspaniałą nogę i kolano najrasowsze $\mathrm{w}$ świecie ${ }^{17}$.

W 1883 roku malarz zadecydował o powrocie do ojczyzny, jednak po zawarciu małżeństwa z Marią Kisielnicką ponownie odwiedził stolicę Francji z nowo poślubioną małżonką. Magdalena Samozwaniec, młodsza córka Wojciecha, utrwaliła wspomnienia swojej matki na kartach Marii i Magdaleny:

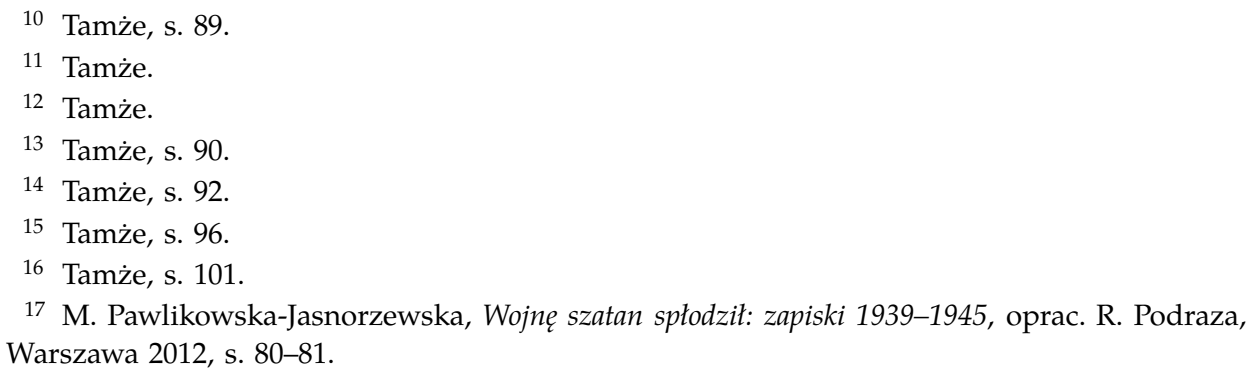


Maryleczka [Maria z Kisielnickich Kossak - dop. E.A.] opowiadała swoim córkom, że nigdy przedtem ani potem nie była tak szczęśliwa. Młody mąż nie tylko nosił ją na rękach, ale oprowadzał po całym Paryżu, pokazywał jej dzieła sztuki w Luwrze, uczył ją patrzeć na piękno architektury Paryża swoim artystycznym wzrokiem, wysiadywał $\mathrm{z}$ nią $\mathrm{w}$ kawiarniach ${ }^{18}$ na bulwarach, prowadził wieczorem do Opery, do Comédie Française, gdzie występowała Sara Bernhardt [...]. Prowadził ją też na wieczorki muzyczne do księżnej Marceliny Czartoryskiej, uczennicy Szopena, gdzie zbierała się cała paryska artystyczna Polonia i świat arystokratyczny ${ }^{19}$.

Po powrocie z paryskiego wojażu Wojciech zamieszkał wraz z małżonką w Krakowie. Juliusz Kossak zmagał się z poważnymi problemami finansowymi i tylko dzięki posagowi Marii z Kisielnickich Kossak willa Kossakówka została w rękach rodu ${ }^{20}$. Pomimo założenia rodziny i osiedlenia się w Krakowie, Wojciech Kossak nadal sporo podróżował. W 1901 roku został kawalerem Orderu Legii Honorowej. Zdarzenie to, potwierdzone w 158 numerze czasopisma „Bulletin polonais littéraire, scientifique et artistique” 21, zostało dokładniej opisane we Wspomnieniach batalisty. Kandydaturę Kossaka do odznaczenia przedstawił marquis de Noailles ${ }^{22}$, dekoracji Orderem dokonał w ambasadzie austriackiej hrabia Szapara ${ }^{23}$. Malarz, który często odwiedzał Francję, dumnie nosił to wyróżnienie: "Zakładam ją z prawdziwą przyjemnością już na granicy, czy w Jeumont, czy w Deutsch Avricourt, bo jest to na każdym kroku we Francji passepartout i legitymacja najlepsza" 24 .

Magdalena Samozwaniec zapamiętała kilkumiesięczne wyjazdy ojca do Paryża, gdzie dzieła artysty były prezentowane na wielu wystawach ${ }^{25}$. Stęskniony Wojciech wysyłał swoim córkom eleganckie francuskie kapelusze

18 Wojciech Kossak był stałym bywalcem Café Tortoni przy Boulevard des Italiens. Miejsce to odwiedzała paryska bohema XIX wieku [zob. W. Kossak, Wspomnienia, s. 101]. Kawiarnia funkcjonuje do tej pory i szczyci się renomą.

19 M. Samozwaniec, Maria i Magdalena, t. 1, Szczecin 1989, s. 178.

20 Juliusz Kossak wraz z Zofią z Gałczeńskich Kossak przenieśli się wówczas do oficyny, która mieściła się przy głównej willi wcześniej zwanej „Wygodą”. Oficyna we wspomnieniach Magdaleny Samozwaniec została mianowana „Domkiem Babci” [zob. M. Samozwaniec, Moich listów nie pal, s. 217].

21 A. Wierzbicka, Świadectwa obecności. Polskie życie artystyczne we Francji w latach 1900-1939, diariusz wydarzeń z wyborem tekstów, lata 1900-1921, Warszawa 2012, s. 79.

22 Emmanuel Henri de Noailles (1830-1909), ambasador francuski w Berlinie.

23 W. Kossak, Wspomnienia, s. 146-147.

24 Tamże, s. 93.

25 Dzieła Wojciecha Kossaka oraz Juliusza Kossaka były bardzo często prezentowane paryskiej widowni, o wszystkich istotnych wystawach od 1900 roku pisze Anna Wierzbicka. Zob. A. Wierzbicka, Świadectwa obecności. Polskie życie artystyczne we Francji w latach 1900-1939, dia- 
ozdobione piórami, tiulami i kwiatami ${ }^{26}$. Sam malarz nie przejmował się zaściankowym społeczeństwem Krakowa przełomu XIX i XX wieku, nosił eleganckie stroje, zaprojektowane na wzór mody francuskiej oraz angielskiej ${ }^{27}$.

Zgodnie z ówcześnie panującą etykietą córki Wojciecha od najmłodszych lat pobierały nauki języka francuskiego ${ }^{28}$. Rodzice prenumerowali dla nich tygodnik „Petit Français Illustré” 29 , który był adresowany dla panienek z dobrych domów. Młode Kossakówny czytywały także francuską literaturę, m.in. powieści Juliusza Verne'a ${ }^{30}$. Obycie Magdaleny oraz Marii Pawlikowskiej-Jasnorzewskiej z paryską kulturą i stylem życia było na tyle duże, że pewne elementy francuskiej obyczajowości przenikały do ich życia codziennego, tak jak rytuał parzenia zielnych naparów na modłę dam kosztujących ich w kawiarni u Rumpelmayera ${ }^{31}$.

Dorosłe córki Wojciecha Kossaka często odwiedzały Francję, m.in. Paryż oraz Niceę. W 1925 roku, wracając z wakacji na francuskim wybrzeżu, Magdalena Samozwaniec i Maria Pawlikowska zatrzymały się w Paryżu, w którym przygotowywano się w tym czasie do Międzynarodowej Wystawy Sztuki Dekoracyjnej i Zdobnictwa:

Wielu znajomych malarzy i architektów urządzało polski pawilon. Od razu [siostry - dop. E.A.] wpadły w polską cyganerię, w kompanię Stryjeńskich, Puszetów, Warchałowskich itp. Madzia i Lilka ${ }^{32}$ ze swoim mężem ${ }^{33}$ i Jarosławem Iwaszkiewiczem poszli złożyć wizytę Oldze Boznańskiej, która hodowała myszy $^{34}$. Słynna malarka wyglądała, jak gdyby była przez siebie samą wymalowanym portretem: blada, popielata, jakby zasnuta jakąś zaświatową pajęczyną, w czarnej sukni zapiętej pod szyję ${ }^{35}$.

riusz wydarzeń z wyborem tekstów, lata 1900-1921, t. 1, Warszawa 2012; tejże, Świadectwa obecności. Polskie życie artystyczne we Francji w latach 1900-1939, diariusz wydarzeń z wyborem tekstów, 1922-1929, t. 2, Warszawa 2015; tejże, Świadectwa obecności. Polskie życie artystyczne we Francji w latach 1900-1939, diariusz wydarzeń z wyborem tekstów, 1930-1939, t. 3, Warszawa 2016.

26 M. Samozwaniec, Maria i Magdalena, t. 1, s. 74.

27 Tamże.

28 Tamże, s. 43.

29 Tamże, s. 53.

30 Tamże, s. 115.

31 M. Samozwaniec, Zalotnica niebieska, Kraków 1973, s. 45. Anton Rumpelmayer był austriackim cukiernikiem, właścicielem słynnego sklepu herbacianego w Paryżu. Sklep pierwotnie przyjął nazwę po właścicielu, do dziś funkcjonuje pod szyldem „Angelina”.

32 Maria Pawlikowska-Jasnorzewska przez bliskich była nazywana Lilką.

33 Drugim mężem Marii Pawlikowskiej-Jasnorzewskiej był Jan Gwalbert Henryk Pawlikowski.

34 Szerzej o karierze Olgi Boznańskiej w Paryżu pisze Ewa Bobrowska [zob. E. Bobrowska, Emancypantki? Artystki polskie w Paryżu na przełomie XIX i XX wieku, „Archiwum Emigracji. Studia - Szkice - Dokumenty" 2012, z. 1-2, s. 11-27].

35 M. Samozwaniec, Maria i Magdalena, t. 1, s. 195. 
Wydarzenie to zapamiętał i zrelacjonował na łamach "Życia Warszawy" w 1979 roku, wspominany przez Samozwaniec, Jarosław Iwaszkiewicz:

Lilka i Madzia w Paryżu na wystawie sztuki dekoracyjnej. Mieszkały w Hotel du Louvre i brylowały na parkietach ambasady i na popijawie $\mathrm{w}$ pracowni Gucia Zamoyskiego. Było wspaniałe śniadanie u mojego przyszywanego wuja Gucia Taubego, gdzie obok Madzi błyszczała (czego ona nie lubiła) także Zofia Stryjeńska ${ }^{36}$.

Maria Pawlikowska-Jasnorzewska spotykała polską bohemę żyjącą w Paryżu także po rozwodzie z Janem Gwalbertem Henrykiem Pawlikowskim. Autorka Pocałunków wdała się wówczas w romans z portugalskim poetą i lotnikiem Sarmento de Beiresem i powróciła do stolicy Francji, gdzie przebywał jej adorator. Relacja ta nie trwała jednak długo i opuszczona przez mężczyznę pisarka spędziła resztę swojego pobytu w Paryżu w towarzystwie przyjaciół, m.in. Karola Stryjeńskiego, Augusta Zamoyskiego i Aleksandra Janty-Połczyńskiego. Artyści spotykali się w polskiej restauracji „u Bartka”, gdzie spożywali dania pochodzące z tradycyjnej polskiej kuchni, na przykład kaszę z barszczem ${ }^{37}$.

W 1929 roku Pawlikowska-Jasnorzewska wydała tomik Paryż, który zawiera wiersze $\mathrm{w}$ większości nawiązujące tematycznie do tytułowego miasta. Widzianą oczami poetki magiczną paryską atmosferę oddają szczególnie dwa pierwsze utwory z tomu - Paryż oraz Czarownicy Paryża. Pawlikowska, choć utrwaliła na kartach swoich wierszy najpiękniejsze zakamarki stolicy, przedstawiła je jako miejsce groźne, mroczne, przepełnione złą energią ${ }^{38}$.

Jeden z utworów opublikowanych w „Pologne Littéraire” w 1931 roku odzwierciedla wspomnianą powyżej aurę:

\section{Topielice}

Rudą nocą, pod mostem, w Sekwanie płynie kotka, przemokła i sina.

Pod następnym mostem niespodzianie, przyłączyła się do niej dziewczyna.

\footnotetext{
36 J. Iwaszkiewicz, „Życie Warszawy” 1979, nr 81; M. Brandys, Dzienniki 1972, Warszawa 1996, s. 16, 116-117, cyt. za: R. Podraza, Córka Kossaka, wspomnienia o Magdalenie Samozwaniec, Warszawa 2008, s. 86.

37 M. Samozwaniec, Maria i Magdalena, t. 2, Szczecin 1989, s. 200.

38 Szerzej o mityzacji przestrzeni miejskiej Paryża w twórczości M. Pawlikowskiej pisze Paulina Stachula [zob. P. Stachula, Mityzacja przestrzeni miejskiej Krakowa i Paryża w poezji Marii Pawlikowskiej-Jasnorzewskiej, "Zeszyty Naukowe Towarzystwa Doktorantów UJ. Nauki Humanistyczne", nr specjalny 5 (1/2014), s. 91-107].
} 
Opryskują je lampy portowe,

owijają je posępne fale,

a one prowadzą rozmowę,

nie oddychając już wcale.

„Dzieci z mostu mnie w wodę wrzuciły.

A ciebie?" - „I mnie także. Wiedz to...

Choć tak bliskie, dalekie, bez siły,

w zimną falę rzuciło mnie dziecko.

Teraz we mnie odpływa jak w łodzi,

w dal od brzegów, tonących w mgły krepie...

Nie zobaczy już świata”. - „Nie szkodzi..."

- Nie wyrośnie na ludzi..." - „To lepiej...” 39

Twórczość Magdaleny Samozwaniec także zawiera teksty poświęcone Paryżowi. Na zbiór satyrycznych historyjek z podróży Pod siódmym niebem złożyły się m.in. trzy obrazki, opowiadające w humorystyczny sposób o „Parandyżu” z lat 1931-19370. Satyryczka, z charakterystyczną dla siebie "solą attycką" przedstawiała w nich przywary Francuzów, ówczesną modę francuską, paryskie kawiarnie czy popularne w tamtych czasach bistro. Samozwaniec pokpiwała także z renomy, jaką szczyci się stolica Francji:

Paryż zwie się ogólnie „miastem świateł”. Jest to zresztą nazwa trafna, ponieważ stolica świata na rzęsistą poświatę elektryczną nie żałuje pieniędzy. Wspaniałym oświetleniem reklamuje się z daleka przecudny Place de la Concorde, nawet Wenus Milońska, oświetlana w niektóre dnie, wygląda - gdy się wejdzie wieczorem do Luwru - jak świetlna reklama posągów greckich ${ }^{41}$.

Z całą pewnością można stwierdzić, że Magdalena Samozwaniec ceniła styl paryżanek ${ }^{42}$. Jednym z jej ulubionych domów mody był Dom Mody Chanel. Pisarka zaglądała do butiku Gabrielle Chanel przy Rue Cambon, gdzie pewnego razu zakupiła klipsy ${ }^{43}$. Co ciekawe, uważała, że Francuzi są narodem oszczędnym, wręcz skąpym, w przeciwieństwie do rozrzutnych, wciąż sarmackich Polaków ${ }^{44}$.

\footnotetext{
39 M. Pawlikowska-Jasnorzewska, Złote myśli kobiety. Wiersze zebrane, red. M. Nalewski, Warszawa 2019, s. 271.

40 M. Samozwaniec, Pod siódmym niebem, Warszawa 1960, s. 70-86.

41 Tamże, s. 81.

42 Zachowała się radiowa audycja z 1970 roku, w której Samozwaniec wspomina o współczesnej modzie oraz o francuskim stylu: https://www.polskieradio.pl/39/156/Artykul/957179, Magdalena-Samozwaniec-tropicielka-nonsensow [dostęp 17.01.2020].

43 M. Samozwaniec, Z pamiętnika niemłodej już mężatki, s. 197.

44 Tamże, s. 199.
} 
W 1939 roku Maria Pawlikowska-Jasnorzewska opuściła Warszawę wraz ze swoim trzecim mężem Stefanem Jasnorzewskim - polskim kapitanem lotnictwa, który podczas II wojny światowej pełnił zawodowe obowiązki poza granicami kraju. Elżbieta Hurnikowa wykazała, że miejscem pobytu małżonków od 7 stycznia 1940 roku był Paryż ${ }^{45}$. Podczas wojennej tułaczki Pawlikowska czuła się we Francji niemal jak w drugim domu, gdyż znała kulturę oraz język kraju, do którego trafiła. Zupełnie inny charakter miały doświadczenia emigracyjne artystki w Anglii, gdzie borykała się z problemami komunikacyjnymi i poczuciem wyobcowania, co prawdopodobnie wpłynęło na szybszy rozwój trawiącej ją choroby nowotworowej i ostatecznie doprowadziło do przedwczesnej śmierci.

W emigracyjnych zapiskach Pawlikowska-Jasnorzewska zanotowała moment wkroczenia wojsk hitlerowskich do Paryża:

Niemcy są już, zdaje się, w Paryżu. Nasze małe radio Lutin nadaje przesmutne jakieś symfonie ze stacji paryskiej. Żal po mojej Francji najdroższej - mogę tylko płakać, co nie będzie ani pięknym widokiem, ani wzruszającym i pożytecznym czynem. Gruźlica straszliwa zajmuje organ po organie w całości Europy, zajęła mózg - siedlisko cywilizacji, światło świata - Paryż ${ }^{46}$.

Choć powyższa informacja poprzedza jednym dniem zajęcie przez Niemców Paryża, oddaje stosunek emocjonalny poetki do podbitego miasta.

Magdalena Samozwaniec przebywała w tym czasie w Krakowie, wraz z Wojciechem Kossakiem oraz Marią z Kisielnickich Kossak. Pisarka dowiedziała się o wejściu wojsk hitlerowskich do Paryża z audycji radiowej, nadawanej w języku francuskim. Jej reakcja była równie emocjonalna i intensywna:

nadawało Radio Paryż, nadawało komunikat, że wojska niemieckie wkraczają do stolicy i odbywa się defilada na Polach Elizejskich... Popłakałam się strasznie, nie mogłam mówić [...]. Nie mogłam ani jeść, ani pić, poza tym było mi jakoś dziwnie, jakby umarł ktoś najbliższy... ${ }^{47}$.

Wrażenie, jakie wywołała na obu siostrach informacja o zajęciu Paryża przez Niemców można chyba porównać tylko z lękiem o losy Polski ${ }^{48}$.

\footnotetext{
45 M. Pawlikowska-Jasnorzewska, Z Toba jedynym, oprac. E. Hurnikowa, Warszawa 2015, s. 26.

${ }^{46}$ M. Pawlikowska-Jasnorzewska, Wojne szatan spłodzit, s. 38-39.

47 M. Samozwaniec, Z pamiętnika niemłodej już mężatki, s. 181.

48 Świadczy o tym m.in. dramat M. Pawlikowskiej-Jasnorzewskiej Baba-Dziwo, wystawiany jeszcze w 1939 roku.
} 
Podczas wojny, w 1942 roku, zmagając się z nowotworem, odszedł Wojciech Kossak, nie doczekawszy się ani wolnej Polski, ani wolnego Paryża. W 1945 roku, po trzech operacjach, zmarła poetka Maria Pawlikowska-Jasnorzewska. Nigdy nie powróciła do ojczyzny. Została pochowana w Manchesterze, na Southern Cemetery. Magdalena Samozwaniec przeżyła wojnę, lecz opuściła powojenny Kraków, gdyż uważała, że miasto to po śmierci najbliższych stało się dla niej wrogie ${ }^{49}$. Satyryczka zamieszkała ze swoim drugim mężem, Zygmuntem Niewidowskim, w Warszawie. Samozwaniec sporo podróżowała, także do Paryża. Najprawdopodobniej ostatni raz odwiedziła stolicę Francji na przełomie 1969 i 1970 roku.

Związki polskich artystów z Paryżem od XIX wieku do czasów II wojny światowej odznaczała wielka zażyłość - jej świadectwa można znaleźć choćby w antologii opracowanej przez Annę Wierzbicką ${ }^{50}$. Do grona admiratorów tego miasta z pewnością można zaliczyć również Kossaków, na których biografię i twórczość stolica Francji wywarła ogromny wpływ.

\section{Bibliografia}

Bobrowska Ewa (2012), Emancypantki? Artystki polskie w Paryżu na przełomie XIX $i \mathrm{XX}$ wieku, „Archiwum Emigracji. Studia - Szkice - Dokumenty”, z. 1-2, s. $11-27$.

Kossak Wojciech (2016), Wspomnienia, oprac. K. Olszański, Warszawa: Pax.

Pawlikowska-Jasnorzewska Maria (2012), Wojne szatan spłodzit: zapiski 1939-1945, oprac. R. Podraza, Warszawa: Agora.

Pawlikowska-Jasnorzewska Maria (2019), Złote myśli kobiety. Wiersze zebrane, red. M. Nalewski, Warszawa: Prószyński Media.

Pawlikowska-Jasnorzewska Maria, Jasnorzewski Stefan (2015), Z Toba jednym. Listy Marii Pawlikowskiej-Jasnorzewskiej i Stefana Jasnorzewskiego, oprac. E. Hurnikowa, Warszawa: W.A.B.

Podraza Rafał (2008), Córka Kossaka, wspomnienia o Magdalenie Samozwaniec, Warszawa: Instytut Wydawniczy Latarnik.

Samozwaniec Magdalena (1960), Pod siódmym niebem, Warszawa: Wydawnictwo MON.

Samozwaniec Magdalena (1973), Zalotnica niebieska, Kraków: Wydawnictwo Literackie.

Samozwaniec Magdalena (1989), Maria i Magdalena, t. 1-2, Szczecin: Glob.

49 M. Samozwaniec, Z pamiętnika niemłodej już mężatki, s. 10.

50 A. Wierzbicka, Artyści polscy w Paryżu, antologia teksów o polskiej kolonii artystycznej czynnej w latach 1900-1939, Warszawa 2008. 
Samozwaniec Magdalena (2010), Z pamiętnika niemłodej już mężatki, oprac. R. Podraza, Warszawa: W.A.B.

Samozwaniec Magdalena (2014), Moich listów nie pal. Listy do rodziny i przyjaciót, oprac. R. Podraza, Warszawa: W.A.B.

Stachula Paulina (2014), Mityzacja przestrzeni miejskiej Krakowa i Paryża w poezji Marii Pawlikowskiej-Jasnorzewskiej, „Zeszyty Naukowe Towarzystwa Doktorantów UJ. Nauki Humanistyczne", nr specjalny 5 (1/2014), s. 91-107.

Wierzbicka Anna [oprac.] (2008), Artyści polscy w Paryżu, antologia teksów o polskiej kolonii artystycznej czynnej w latach 1900-1939, Warszawa: Neriton, Instytut Sztuki PAN.

Wierzbicka Anna [oprac.] (2012), Świadectwa obecności. Polskie życie artystyczne we Francji w latach 1900-1939, diariusz wydarzeń z wyborem tekstów, lata 1900-1921, t. 1, Warszawa: Neriton, Instytut Sztuki PAN.

Wierzbicka Anna [oprac.] (2015), Świadectwa obecności. Polskie życie artystyczne we Francji w latach 1900-1939, diariusz wydarzeń z wyborem tekstów, 1922-1929, t. 2, Warszawa: Neriton, Instytut Sztuki PAN.

Wierzbicka Anna [oprac.] (2016), Świadectwa obecności. Polskie życie artystyczne we Francji w latach 1900-1939, diariusz wydarzeń z wyborem tekstów, 1930-1939, t. 3, Warszawa: Neriton, Instytut Sztuki PAN.

Ziejka Franciszek (2008), Mój Paryż, Kraków: Universitas.

\title{
The Paris of Kossaks: Family Reminiscences
}

\begin{abstract}
The article discusses the ties of the Kossak family with the nineteenthand twentieth-century Paris, tracing the facts in the existing artistic works and memoirs. The author concentrates on the artistic connections, especially concerning Juliusz, the progenitor of the Kossak family, with the Parisian artists and Polish modernist bohemia. The author shows the strong connections between Wojciech Kossak, Maria Pawlikowska-Jasnorzewska and Magdalena Samozwaniec and Paris, and she proves that the city was the source of creative inspiration.
\end{abstract}

Keywords: Polish diaspora in Paris, bohemia, memoir writing, Kossak family 